\title{
Comparison of post-operative outcomes of graft materials used in reconstruction of blow-out fractures
}

\author{
단 Serdar Düzgün, M.D., ${ }^{1}$ ำ Bahar Kayahan Sirkeci, M.D. ${ }^{2}$
}

1Department of Plastic and Reconstructive Surgery, Yüksek İhtisas University Faculty of Medicine, Liv Hospital Ankara, Ankara-Turkey
${ }^{2}$ Department of Ear Nose Throat and Head and Neck Surgery, Yüksek İhtisas University Faculty of Medicine, Liv Hospital Ankara, Ankara-Turkey

\begin{abstract}
BACKGROUND: Trauma to the face caused by assault or impact may cause internal orbital fracture. Increased intraorbital pressure without disruption of soft tissue integrity or causing a fracture line in orbital rims or orbital floor fractures described as "orbital blowout fracture". Such fractures have been categorized as "pure blow-out fractures" in which only the orbital floor is affected, and "impure blow-out fractures" in which other maxillofacial bones such as zygoma, maxilla and nasoethmoid are also affected. Physical examination reveals periorbital edema and ecchymosis, subconjunctival hemorrhage, limitation of eye globe movements, diplopia, enophthalmos, dystopia, and infraorbital hypoesthesia. Reconstruction of the orbital bony structures is the most important issue to preserve the standard orbital functions and providing an aesthetic view. Although many surgical approaches have been defined in the literature regarding the attitude and timing of treatment, no consensus exists. In literature; many autogenous and alloplastic biomaterials have been recommended to correct orbital bone defects.
\end{abstract}

METHODS: This study aims to compare postoperative outcomes of patients presenting with pure and impure blow-out fractures repaired with cartilage, bone grafts, titanium mesh or porous polyethylene implant. Sixty-four orbital floor fractures of 62 cases were included in this research who admitted to our clinic with maxillofacial trauma between $20 \mathrm{II}$ and 20I8. All patients underwent maxillofacial radiological examination; Waters radiography and also axial-coronal plane maxillofacial and orbital computerized tomography.

RESULTS: Permanent, post-operative, vertical diplopia in extreme gazes was detected in 3 of I4 patients in whom the orbital floor was reconstructed with an iliac bone graft. Two of nineteen cases who underwent reconstruction using auricular conchal cartilage graft had vertical diplopia in extreme gazes four months after the operation. The implant extruded and became palpable in 2 of I5 patients in the porous polyethylene implant group. None of the patients in the iliac bone and conchal cartilage autograft groups was presented late postoperative enophthalmos according to the graft resorption. In titanium mesh group, I of eleven patients had permanent, postoperative vertical diplopia in extreme gazes. None of the patients in this group developed any donor area complications, infection, or implant extrusion.

CONCLUSION: Results show that the auricular conchal cartilage graft was the best biomaterial used to repair defects smaller than $4 \mathrm{~cm}^{2}$, where as titanium mesh was a good option to repair defects larger than $4 \mathrm{~cm}^{2}$. However, selection of the optimal biomaterial to be used to repair orbital blow-out fractures should be made according to patient characteristics and preoperative findings, the severity of the injury, the cost of the biomaterial to be used, and surgeon's expertise.

Keywords: All-plastic biomaterials; autogenous grafts; blow-out fractures.

\section{INTRODUCTION}

Cranio-maxillo-facial fractures involving the orbits are fre-

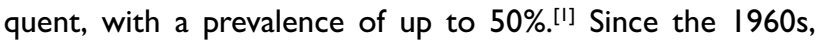
orbital fractures have been categorized into two groups - "pure" and "impure" regarding the preservation of the orbital rim. ${ }^{[2]}$ Pure orbital fractures are limited to the orbital walls, whereas impure orbital fractures involve the adjacent facial bones, such as in orbitozygomatic, naso-orbito-ethmoidal, Le Fort II or III, or panfacial fractures. ${ }^{[3]}$

Cite this article as: Düzgün S, Kayahan Sirkeci B. Comparison of post-operative outcomes of graft materials used in reconstruction of blow-out fractures. Ulus Travma Acil Cerrahi Derg 2020;26:538-544.

Address for correspondence: Bahar Kayahan Sirkeci, M.D.

Yüksek İhtisas Üniversitesi Tıp Fakültesi, Liv Hospital Ankara, Kulak Burun Boğaz ve Baş Boyun Cerrahisi Bölümü, Ankara, Turkey

Tel: +90 312 - 3291010 E-mail: baharkayahan@hotmail.com

Ulus Travma Acil Cerrahi Derg 2020;26(4):538-544 DOI: 10.14744/tjtes.2020.80552 Submitted: 18.12.2019 Accepted: 06.05.2020 Online: I5.06.2020

Copyright 2020 Turkish Association of Trauma and Emergency Surgery 
Pure blow-out fractures constitute $2.8-21.4 \%$ of the maxillofacial injuries. ${ }^{[2,3]}$ Physical examination reveals periorbital edema and ecchymosis, subconjunctival hemorrhage, limitation of eye globe movements, diplopia, enophthalmos, dystopia, and infraorbital hypoesthesia. Enophthalmos is defined as the posterior displacement of the eyeball due to volume changes in the bony orbit and the disruption of orbital content. Two to three millimeters of enophthalmos is clinically detectable, and more than $5 \mathrm{~mm}$ is disfiguring. ${ }^{[4]}$

Although there is not any strict consensus on the indications for surgical repair of orbital floor fractures, mechanical muscle compression causing diplopia is one of the surgical indications. This situation can be identified using the forced duction test or imaging techniques. Another indication is the persistence of progressive enophthalmos following resolution of trauma-induced edema. Many surgeons believe that defects more significant than $\mathrm{I} \mathrm{cm}^{2}$ require surgery as they cause enophthalmos. ${ }^{[4]}$

Many conventional strategies have been used to correct posttraumatic enophthalmos. Many autogenous and alloplastic biomaterials have been recommended to correct bony orbit, such as autogenous bone grafts, cartilage grafts, fascia grafts and artificial prostheses (using absorbable or nonabsorbable materials). ${ }^{[2,5]}$ Resorption of the graft, longer operation time, and donor area morbidity are the main factors limiting the use of autogenous grafts. ${ }^{[6-8]}$ These drawbacks are especially prominent in bone grafts.

For a partial solution to the inherent disadvantages of autogenous grafts, allogenic materials have also been used to correct bony orbit defects. Allografts used for this indication include lyophilized dura mater, demineralized bone, irradiated cartilage, irradiated fascia and acellular dermal matrix. An ideal implant material should be sterilizable, chemically inert, nonallergic, non-carcinogenic, biocompatible, easy-to-remove, malleable, cost-effective, and resistant to deformation and stress. Also, it should not induce a foreign body reaction or create a medium for the growth of microorganisms. ${ }^{[4,9-11]}$ To allow radiographic evaluation, radio-opaque materials that do not form any artifacts are preferred. The main problems due to the use of these materials are infection and extrusion risks.

This study aims to compare postoperative outcomes of patients presenting with pure and impure blow-out fractures repaired with cartilage, bone grafts, titanium mesh or porous polyethylene implant.

\section{MATERIALS AND METHODS}

Sixty-four orbital floor fractures of 62 cases were included in this research who admitted to our clinic with maxillofacial trauma between $201 \mathrm{I}$ and 2018 . Forty-seven (76\%) of the patients were male, and 15 (24\%) were female, mean age was 32 years (ranging between 15-54 years).
All patients underwent maxillofacial examination, waters radiography and also axial-coronal plane maxillofacial and orbital computerized tomography. Evaluation of the radiographic and physical examination results revealed a unilateral blow-out fracture in 60 of 62 patients and bilateral blow-out fractures in two patients (Fig. I). Of the 64 orbital fractures, 26 were pure, and 38 were impure blow-out fractures.

A pre-operative ophthalmology consultation was obtained for all cases. An ophthalmologist using a Hertel exophthalmometry assessed the existence of enophthalmos. $2 \mathrm{~mm}$ or more posterior displacement was stated as enophthalmos. Ocular examination showed diplopia in vertical gaze in 31 patients, diplopia plus enophthalmos in II patients, and isolated

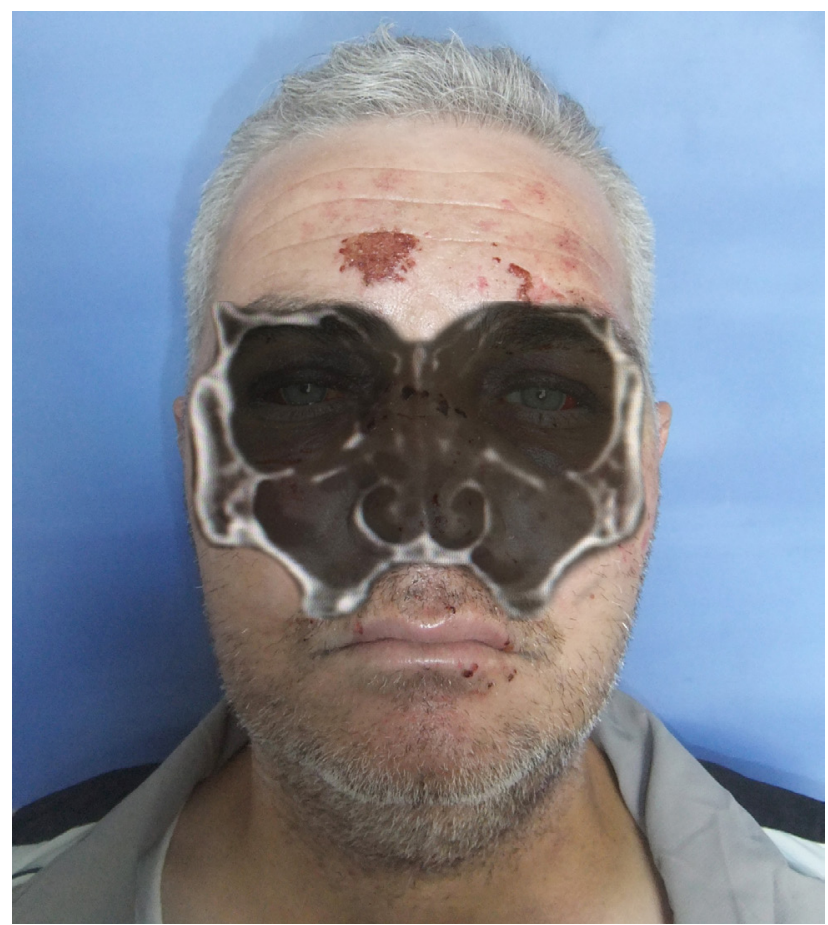

Figure 1. Bilayered image of the bilateral blow-out fracture.

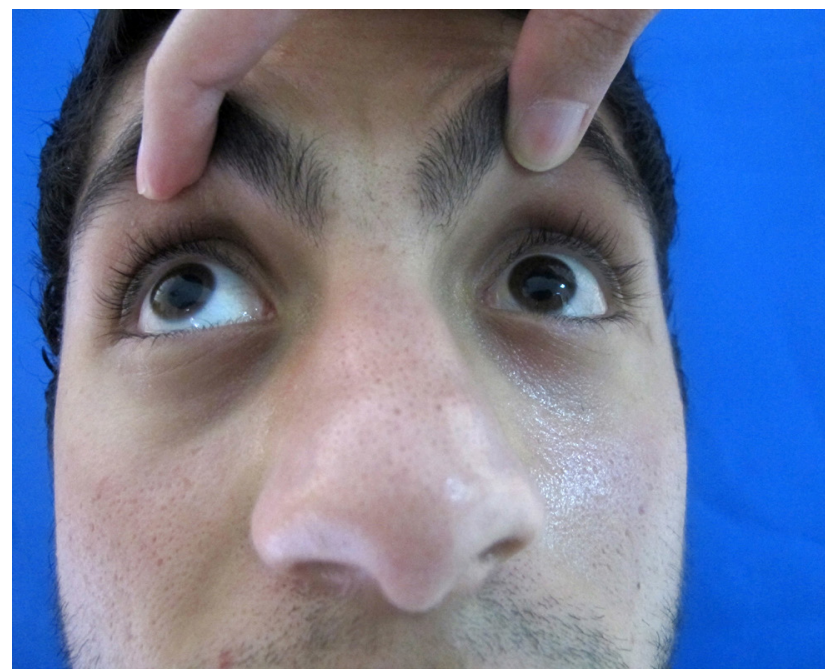

Figure 2. Upward gaze impairment. 
dystopia in nine patients, upward gaze impairment of a case is shown in Figure 2. In addition to the results from coronal orbital tomography, the surgical indications were the presence of diplopia, dystopia, enophthalmos, and accompanying fracture(s). Eleven patients had a routine physical examination but underwent surgery because orbital tomographic images showed a defect larger than ${\mathrm{I} \mathrm{cm}^{2}}^{2}$ on the orbital floor. The median time from the trauma to the operation was eight days (ranging from two to 60 days). The clinical approach was to operate all patients within the first ten days after the trauma. However, seven patients were operated more than 15 days after the trauma because of the delayed presentation or concurrent medical conditions.

All patients went under general anesthesia for surgery. Using suspension sutures, traction was applied on the lower eyelid and using a subciliary incision; the muscle-skin flap was elevated, and the orbital floor was accessed. Releasing the orbital contents compressed within the defect as necessary exposed the defect. To reconstruct the orbital floor defects, iliac bone graft was used in 14 patients, auricular conchal cartilage graft was used in 19 patients, ultra-thin porous polyethylene sheet $(0.85 \mathrm{~mm}$ thick) was used in 15 patients, and titanium mesh was used in 16 patients.

The conchal cartilage graft (Fig. 3) was placed as the perichondrium facing through the maxillary sinus. The titanium

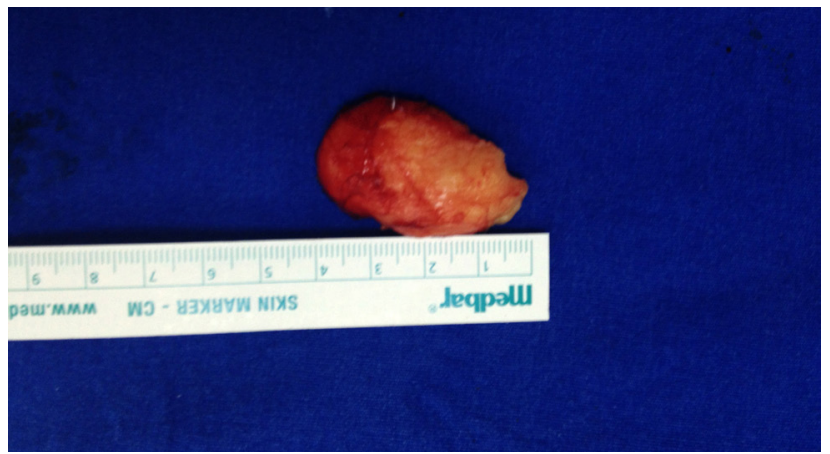

Figure 3. Harvested cartilage graft.

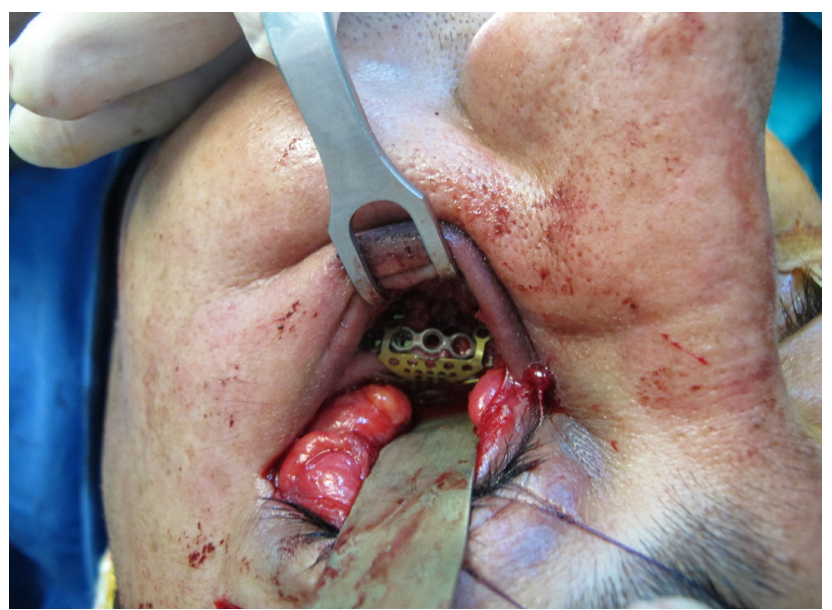

Figure 4. The titanium mesh placed to the orbital floor defect. mesh implants were fixed to the lower orbital rim using two micro screws (Fig. 4). Shapes of all autologous and alloplastic implants were modified to fit the defect and orbital floor. After placement of the implant, eye globe movements were tested with the forced duction test. After determining that eye globe movements in all directions become unrestricted, canthopexy was performed to prevent post-operative lower eyelid retraction, and then the incision was closed with double layers of $5 / 0$ polyglactin suture. Reduction and plaque-screw fixations of all fractures of other maxillofacial bones accompanying the orbital floor fracture were performed simultaneously with the orbital floor fracture reconstruction.

The suspension sutures in the lower eyelid were removed on the second day after surgery, and the patients were instructed to massage the eye to prevent lower eyelid retraction. The patients were followed postoperatively for six to 31 months, with a mean follow-up of 14 months. All patients had ophthalmology consultation at the follow-up to assess enophthalmos existence by Hertel exophthalmometry, even the late postoperative period.

\section{RESULTS}

Permanent, post-operative, vertical diplopia in extreme gazes was detected in three of 14 patients in whom the or-

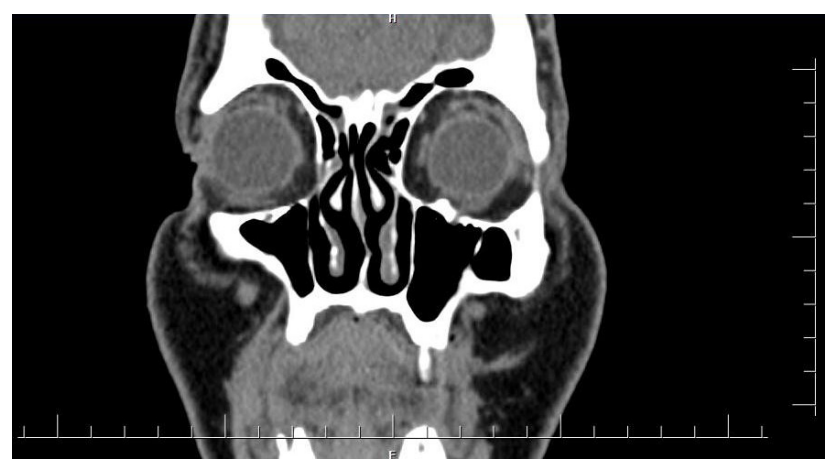

Figure 5. Maxillofacial CT left orbital bone graft postop. 6. months.

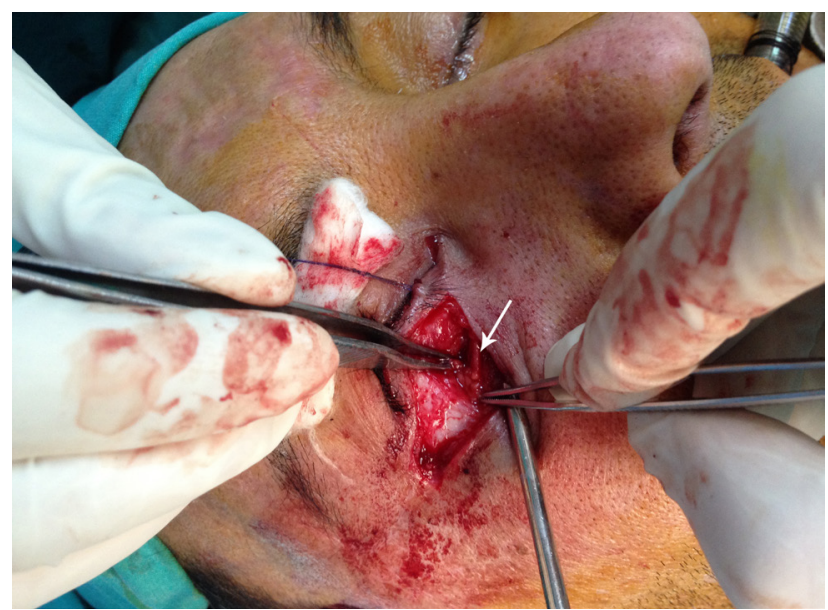

Figure 6. Extrusion of the medpor. 


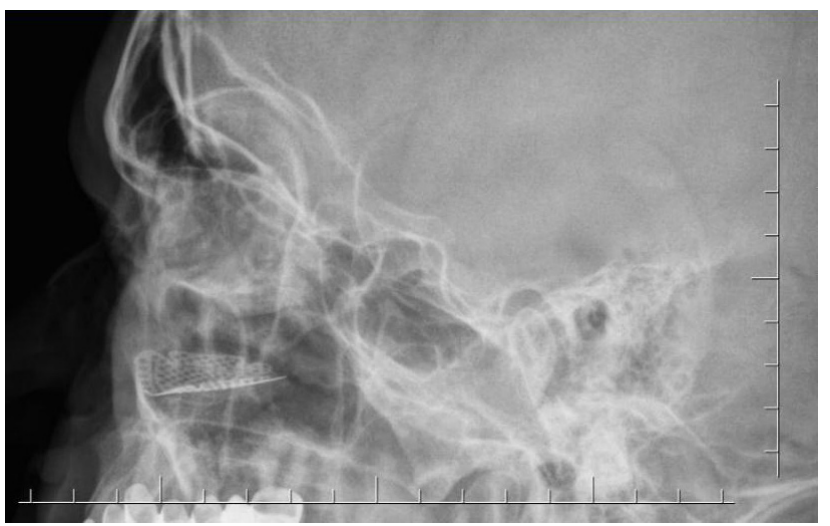

Figure 7. Radiographic image of the implanted titanium mesh.

bital floor was reconstructed with an iliac bone graft. However, since eye globe movements were free in all directions in all of the three patients, diplopia was considered to be the result of muscle contusion. Orbital floor evaluation via maxillofacial CT is seen in Figure 5. Hematoma requiring drainage was developed at the donor area in two patients also in this group. All patients in whom iliac bone graft was used complained about severe pain at the donor area. None of the patients developed an infection or experienced implant extrusion.

Two of nineteen cases who underwent reconstruction using auricular conchal cartilage graft had vertical diplopia in extreme gazes four months after the operation. However, no surgical re-operation was scheduled since eye globe movements were free in all directions. None of the patients in this group developed any donor area complications, infection, or implant extrusion.

The implant extruded and became palpable in two of 15 patients in the porous polyethylene implant group. In one of these patients, the extruded part of the implant was trimmed surgically, and the other patient refused reoperation (Fig. 6). Two patients suffered from permanent upper gaze limitation and vertical diplopia in functional gazes. One of these patients was re-operated one month after the surgery because of persistent enophthalmos. During the operation, it was noticed that there were severe adhesions between the inferior rectus muscle and the implant. Iliac bone graft was placed between the inferior rectus muscle and porous polyethylene implant to reduce the volume of the orbita after releasing the implant from the muscle. Postoperatively, the upper gaze limitation was improved, and enophthalmos was reduced. However, diplopia in straight gaze became permanent, maybe due to incomplete improvement of enophthalmos. The other patient with persistent upper gaze limitation underwent the second operation two months after the first operation. During the second operation, the adhesions between the porous polyethylene implant and the inferior rectus muscle were removed and, to prevent future adhesions, a tensor fascia lata graft was placed between the inferior rectus muscle and the implant. After the operation, the upper gaze limitation improved, but vertical diplopia persisted in functional gazes, perhaps because of inferior rectus injury. None of the patients in this group developed an infection.

In the titanium mesh group, one of eleven patients had permanent, post-operative vertical diplopia in extreme gazes (Fig. 7). Re-operation was not considered to be necessary for that patient. A post-operative infection developed in one diabetic patient in whom the orbital floor was almost completely defective and was reconstructed with a titanium mesh. The patient underwent reduction and fixation with a plaque-screw from the oral cavity for a fragmented fracture in the zygomaticomaxillary region at the same time. Purulent discharge was drained from the maxillary sinus. The site of infection was irrigated with antibiotics regularly, and also intravenous antibiotic therapy was given. The infection regressed, and it was not necessary to remove the titanium mesh. No implant extrusion was observed in any of the patients in this group.

Enophthalmos was persisted in only one patient postoperatively among II patients who had preoperative enophthalmos. This patient had been operated one month after the trauma because of the concurrent medical conditions. The postoperative period of this patient whose orbital floor was reconstructed with porous polyethylene is mentioned before in the text. None of the patients in the iliac bone and conchal cartilage autograft groups was presented late postoperative enophthalmos according to the graft resorption. Biomaterials data are shown in Table I.

Table I. Biomaterials and its properties

\begin{tabular}{lccccccc}
\hline & $\begin{array}{c}\text { Easy } \\
\text { malleability }\end{array}$ & $\begin{array}{c}\text { Extrusion } \\
\text { risk }\end{array}$ & $\begin{array}{c}\text { Infection } \\
\text { risk }\end{array}$ & $\begin{array}{c}\text { Donor area } \\
\text { morbidity }\end{array}$ & $\begin{array}{c}\text { Durability } \\
\text { CCost }\end{array}$ & $\begin{array}{c}\text { Limitation of eye } \\
\text { globe movements }\end{array}$ \\
\hline Bone & + & - & + & ++++ & +++ & - & + \\
Cartilage & ++ & - & + & ++ & +++ & - & - \\
Porous polyethylene implant & ++ & +++ & ++ & - & +++ & ++ & ++ \\
Titanium mesh & +++ & ++ & ++ & - & ++++ & ++ & + \\
\hline
\end{tabular}




\section{DISCUSSION}

There is not any consensus in the literature to clarify the best graft and the most suitable timing of reconstruction of internal orbital fractures. Many authors recommended the use of different synthetic and autogenous biomaterials, each with its advantages and disadvantages, for the reconstruction of orbital floor defects..$^{[4,1-14]}$ In the past, there was a common belief that bone grafts were the most appropriate implant materials for orbital floor reconstruction. ${ }^{[4,5,7]}$ Autogenous bone grafts have been recommended under their ability to provide a more sustained and stable reconstruction. Bone graft donor areas include iliac crest, ribs, calvarium, the anterior wall of the maxilla, and mandible. ${ }^{[13,15]}$

The iliac bone grafts used in our study to reconstruct the orbital floor; however, they have some disadvantages, including the long time required for dissection, the risk of hematoma and pain at the donor area, and more prominent resorption in the graft due to its enchondral origin. ${ }^{[4,13,16]}$ Besides, it is difficult to shape the bone tissue to fit the contour of the orbital floor because of the rigidity.

The advantages of auricular conchal cartilage are more evident because the donor area is closer to the operation field, and harvesting the graft is technically more comfortable and, since the scar is behind the ear, donor area morbidity is negligible. ${ }^{[17]}$ Also, the concave shape of the auricular conchal cartilage is appropriate for the anatomy of the orbital floor, and its elastic and malleable structure facilitates adaptation of the cartilage graft to the defect. ${ }^{[4,12,16]}$ Furthermore, resorption of cartilage grafts occurs less frequently than the resorption of bone grafts. ${ }^{[15]}$ Moreover, the cartilage grafts increase mucosal regeneration when the perichondrium faces the maxillary defect.[ ${ }^{[3]}$ Regarding both the advantages and the disadvantage of size limitation, conchal cartilage grafts are underutilized in orbital floor reconstructions. ${ }^{[16-18]}$

Alloplastic materials are easy to obtain and are not subject to resorption. Synthetic materials are easy to use, but their costs and risks are debatable. Infections, extrusion of the material from the skin, or displacement of the material are the most common complications when synthetic materials are used to repair orbital blow-out fractures. ${ }^{[14-19]}$ Among the alloplastic materials used in our study, the highest complication rate was observed with the porous polyethylene implant as it allows the ingrowth of adjacent tissues into the graft material. Although this is important for stabilization, it may lead to adhesion of the implant to the rectus muscle if the muscle sheath is damaged. Consequently, upper gaze limitation and diplopia developed in two cases of this group. This risk of complication means that a porous polyethylene implant is not suitable for orbital floor reconstruction in patients with a damaged inferior rectus muscle sheath. Besides, properties of the porous polyethylene implants do not prevent implant extrusion since the implants were extruded in two of these patients. To avoid this particular complication, porous polyethylene implants work better if it is fixed to the orbital floor with a screw.

Among alloplastic materials, the best results were obtained when titanium mesh implant was used. The most commonly used material, titanium, has the highest tensile strength despite easily bending, and it is the least corrosive of the metals. Often used in facial bones' fixation, titanium has high biocompatibility with a low risk of infection. It is compatible with radiographic imaging. Titanium mesh is favorable because of a high level of backup and malleability, which allows it to fit large defects or defects involving the medial side of the orbital floor. ${ }^{[14,20,21]}$ Gear et al. ${ }^{[21]}$ reported good functional outcomes and minimal risk of infection in a 44-month follow-up study where orbital floor defects larger than $2 \mathrm{~cm}^{2}$ were reconstructed with titanium mesh in fifty-five patients. Other studies in which titanium mesh was used have similarly reported none or minimal post-operative infection. We encountered no complications with the use of titanium mesh except for one patient who suffered from an infection. Synthetic titanium mesh was preferred, especially in patients with a large orbital floor defect in case cartilage graft could not be used. ${ }^{[22,23]}$

The most common complications after surgical repair of orbital fractures include lower eyelid retraction and enophthalmos, which is usually related to an increase in orbital volume resulting from improper placement of the implant material on the orbital floor. ${ }^{[4,21]}$ Since the orbital floor has a posterior cephalic slope, the implant must be placed in an appropriate anatomical position to fit precisely. ${ }^{[4,21,22]}$ If not, the implant can displace into the maxillary sinus, resulting in an increase in orbital volume and enophthalmos, which is often resistant to corrective surgical interventions..$^{[4]}$ For these reasons, how the implant is placed is more important than the type of implant material that is placed. Effort should be put to restore the orbital volume and contour. It is mandatory to test eye globe movements with the forced duction test after placement of the implant.

Results show that the auricular conchal cartilage graft was the best biomaterial used to repair defects smaller than 4 $\mathrm{cm}^{2}$. It is an easy-to-use biomaterial that fits the anatomical shape of the orbital floor, resulting in minimal donor area morbidity, lower treatment costs, and satisfactory post-operative patient outcomes. Among the synthetic materials tested, titanium mesh was a good option to repair defects larger than $4 \mathrm{~cm}^{2}$. It provides sufficient strength, is easy to use, and is associated with a lower rate of postoperative complications and favorable patient outcomes. However, selecting the optimal biomaterial to be used to repair orbital blow-out fractures should be made according to patient characteristics and preoperative findings, the severity of the injury, and the cost of the biomaterial to be used, and surgeon's expertise. 
Ethics Committee Approval: Approved by the local ethics committee.

Peer-review: Internally peer-reviewed.

Authorship Contributions: Concept: S.D.; Design: S.D., B.K.S.; Supervision: S.D.; Fundings: S.D.; Materials: B.K.S.; Data: B.K.S.; Analysis: B.K.S.; Literature search: B.K.S.; Writing: B.K.S.; Critical revision: S.D., B.K.S.

\section{Conflict of Interest: None declared.}

Financial Disclosure: The authors declared that this study has received no financial support.

\section{REFERENCES}

1. Foletti JM, Scolozzi P. Severe distortion of an orbital titanium mesh implant after recurrent facial trauma: a potential threat to the orbital contents?. Br J Oral Maxillofac Surg 2017;55:836-8. [CrossRef]

2. Converse JM, Cole G, Smith B. Late treatment of blowout fractures of the floor of the orbit. Plast Recons Surg 1961;28:183. [CrossRef]

3. Catherine Z, Courvoisier DS, Scolozzi P. Is the pure and impure distinction of orbital fractures clinically relevant with respect to ocular and periocular injuries? A retrospective study of 473 patients. J Craniomaxillofac Surg 2019;47:1935-42. [CrossRef]

4. Choi JS, Oh SY, Shim HS. Correction of post-traumatic enophthalmos with anatomical absorbable implant and iliac bone graft. Arch Craniofac Surg 2019;20:361-9. [CrossRef]

5. Hollier LH Jr, Kelley P. Soft tissue and skeletal injuries of the face. In: Thorne CH, Beasley RW, editors. Grabb and Smith's Plastic Surgery. 6th edition. Philadelphia: Lippincott Williams and Wilkins; 2006.p.315-31.

6. Sachs ME. Orbital floor fractures: the maxillary approach. Adv Ophthalmic Plast Reconstr Surg 1987;6:387-91.

7. Wilkins RB, Havins WE. Current treatment of blow-out fractures. Ophthalmology 1982;89:464-6. [CrossRef]

8. Patel BC, Hoffmann J. Management of complex orbital fractures. Facial Plast Surg 1998;14:83-104. [CrossRef]

9. Strong EB, Kim KK, Diaz RC. Endoscopic approach to orbital blowout fracture repair. Otolaryngol Head Neck Surg 2004;131:683-95. [CrossRef]

10. Farwell DG, Strong EB. Endoscopic repair of orbital floor fractures. Fa- cial Plast Surg Clin North Am 2006;14:11-6. [CrossRef]

11. Ducic Y, Verret DJ. Endoscopic transantral repair of orbital floor fractures. Otolaryngol Head Neck Surg 2009;140:849-54. [CrossRef]

12. Constantian MB. Use of auricular cartilage in orbital floor reconstruction. Plast Reconstr Surg 1982;69:951-5. [CrossRef]

13. Lin KY, Bartlett SP, Yaremchuk MJ, Fallon M, Grossman RF, Whitaker LA. The effect of rigid fixation on the survival of onlay bone grafts: an experimental study. Plast Reconstr Surg 1990;86:449-56. [CrossRef]

14. Potter JK, Ellis E. Biomaterials for reconstruction of the internal orbit. J Oral Maxillofac Surg 2004;62:1280-97. [CrossRef]

15. Schlickewei W, Schlickewei C. The use of bone substitutes in the treatment of bone defects-the clinical view and history. Macromol Symp 2007; 253:10-23. [CrossRef]

16. Talesh KT, Babaee S, Vahdati SA, Tabeshfar Sh. Effectiveness of a nasoseptal cartilaginous graft for repairing traumatic fractures of the inferior orbital wall. Br J Oral Maxillofac Surg 2009;47:10-3. [CrossRef]

17. Ozyazgan I, Eskitasçioglu T, Baykan H, Coruh A. Repair of traumatic orbital wall defects using conchal cartilage. Plast Reconstr Surg 2006;117:1269-76. [CrossRef]

18. Hendler BH, Gatãeno J, Smith BM. Use of auricular cartilage in the repair of orbital floor defects. Oral Surg Oral Med Oral Pathol 1992;74:719-22. [CrossRef]

19. Kinnunen I, Aitasalo K, Pöllönen M, Varpula M. Reconstruction of orbital floor fractures using bioactive glass. J Craniomaxillofac Surg 2000;28:229-34. [CrossRef]

20. Kraus M, Gatot A, Fliss DM. Repair of traumatic inferior orbital wall defects with nasoseptal cartilage.J Oral Maxillofac Surg 2001;59:1397-401.

21. Gear AJ, Lokeh A, Aldridge JH, Migliori MR, Benjamin CI, Schubert W. Safety of titanium mesh for orbital reconstruction. Ann Plast Surg 2002;48:1-9. [CrossRef]

22. Castellani A, Negrini S, Zanetti U. Treatment of orbital floor blowout fractures with conchal auricular cartilage graft: a report on 14 cases. J Oral Maxillofac Surg 2002;60:1413-7. [CrossRef]

23. Bayat M, Momen-Heravi F, Khalilzadeh O, Mirhosseni Z, Sadeghi-Tari A. Comparison of conchal cartilage graft with nasal septal cartilage graft for reconstruction of orbital floor blowout fractures. Br J Oral Maxillofac Surg 2010;48:617-20. [CrossRef] 


\section{ORIJIINAL ÇALIŞMA - ÖZET}

\section{Blow-out fraktürleri onarımında kullanılan greft materyallerinin ameliyat sonrası sonuçlarının karşılaştırılması \\ Dr. Serdar Düzgün, ${ }^{1}$ Dr. Bahar Kayahan Sirkeci²}

${ }^{1}$ Yüksek İhtisas Üniversitesi Tıp Fakültesi, Liv Hospital Ankara, Plastik ve Rekonstruktif Cerrahi Kiliniği, Ankara

${ }^{2}$ Yüksek İhtisas Üniversitesi Tıp Fakültesi, Liv Hospital Ankara, Kulak Burun Boğaz ve Baş Boyun Cerrahisi Kiliniği, Ankara

AMAÇ: Yüze alınan travmalarda internal orbital hasar görülebilir. Artan intraorbital basınç ile yumuşak doku bütünlüğünü bozulmadan orbital rimde ya da orbita tabanında kırık oluşumuna "blow-out fraktürü" adı verilir. Yalnızca orbita tabanının etkilendiği kırıklar "saf blow-out fraktürü" adı verilirken, zigoma, maksilla ve nazoetmoid kemiklerin de etkilendiği kırıklar "saf olmayan, kompleks blow-out fraktürleri" olarak nitelendirilir. Fizik muayenede periorbital ödem ve ekimiz, subkonjonktival kanama, göz hareketlerinde kısıtllık, diplopi,enoftalmi, distopi ve infraorbital hipoestezi bulguları görülebilir. Orbital kemik yapıların rekonstruksiyonu hem standart göz fonksiyonunun sağlanması hem de estetik görünüm için elzemdir. Cerrahi yaklaşım ve zamanlaması açısından birçok görüş olmasına rağmen bir konsensus oluşmamıştır. Literatürde, orbita kemik defektlerini düzeltilmesi için birçok otojen ve alloplastik biyomateryallerin kullanımı konusunda çalışmalar mevcuttur.

GEREÇ VE YÖNTEM: Bu çalışmada, saf ve kompleks blow-out fraktürü olan, kartilaj ve ya kemik greftleri ile titanyum mesh ya da poroz polietilen implant kullanılarak orbital rekonstrüksiyonu yapılan olguların postoperatif sonuçları karşılaştııılmıştır. 20I I-20I8 yılları arasında kliniğimize maksillofasiyal travma ile başvuran 62 olgunun 64 orbital taban kırı̆ı çalışmaya dahil edildi. Tüm hastalara maksillofasiyal muayene yapıldı, radyolojik olarak Waters radyografi ve ayrıca aksiyal-koronal düzlem maksillofasiyal ve orbital bilgisayarlı tomografi ile değerlendirildi.

BULGULAR: lliyak kemik grefti ile rekonstrüksiyon yapılan 14 hastanın 3'ünde aşırı bakışta kalııı, ameliyat sonrası, dikey diplopi saptandı. Aurikula konkal kartilaj grefti ile rekonstrüksiyon yapılan 19 olgunun ikisinde operasyondan dört ay sonra aşırı bakışlarda dikey diplopi mevcuttu. İmplant, gözenekli polietilen implant grubundaki 15 hastanın 2'sinde ekstrüde oldu ve palpe edilebilir hale geldi. Illiyak kemik ve konkal karitlaj otogreft gruplarında hiçbir hastada greft rezorpsiyonuna göre geç postoperatif enoftalmi izlenmedi. Titanyum mesh grubunda II hastadan I'inde aşırı bakışlarda kalııı, ameliyat sonrası dikey diplopi mevcuttu. Bu gruptaki hiçbir hastada herhangi bir donör bölgesi komplikasyonu, enfeksiyon veya implant ekstrüzyonu gelişmedi. TARTIŞMA: 4 cm²'den küçük defektlere yol açan blow-out fraktürlerinde kullanılabilecek en iyi biyomateryal aurikula konkal kartilaj iken; titanyum mesh $4 \mathrm{~cm}^{2}$ 'den büyük defektleri onarmak için iyi bir seçenek olmuştur. Bununla birlikte, orbita blow-out fraktürlerini onarmak için kullanılacak optimal biyomateryalin seçimi hasta özellikleri ve preoperatif bulgulara, yaralanmanın ciddiyetine, kullanılacak biyomateryalin maliyetine ve cerrahın uzmanlığına göre yapılmalıdır.

Anahtar sözcükler: Alloplastik biyomateriyaller; blow-out kırı̆ı̆; otojen greft.

Ulus Travma Acil Cerrahi Derg 2020;26(4):538-544 doi: 10.14744/tjtes.2020.80552 